\title{
COCONUT GROWERS' KNOWLEDGE, PERCEPTION AND ADOPTION ON IMPACTS OF CLIMATE CHANGE IN GAMPAHA AND PUTTALAM DISTRICTS IN SRI LANKA: AN INDEX-BASED APPROACH
}

(D) Ruvani Subhathma
Wickramarathna Godage $^{1+}$
(D) Bandara
Gajanayake $^{2}$
iD Udith K.
Jayasinghe-Mudalige

Article History

Received: 2 July 2021

Revised: 6 August 2021

Accepted: 30 August 202

Published: 21 September 2021

\section{Keywords}

Coconut

Coconut growers

Adoption

Climate change

Index

Knowledge gap

Perception.

\author{
${ }^{\prime}$ Technology Transfer Officer, Technology Transfer Division, Coconut \\ Research Institute, Bandirippuwa Estate, Lunuwila, Sri Lanka. \\ Email: ruvanigodage@gmail.com Tel: +94771464744 \\ ${ }^{2}$ Professor, Department of Plantation Management, Faculty of Agriculture \\ and Plantation Management, Wayamba University of Sri Lanka, \\ Makandura, Gonawila, Sri Lanka. \\ Email: gajawyb@yahoo.com Tel: +94766255959 \\ ${ }^{s}$ Senior Professor, Department of Agribusiness Management, Faculty of \\ Agriculture and Plantation Management, Wayamba University of Sri \\ Lanka, Makandura, Gonawila, Sri Lanka. \\ Email:udith@wyb.ac.lkTel: +94(71/77)3628911
}

\section{ABSTRACT}

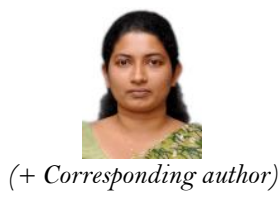

Climate change and food security are critical topics in sustainable agricultural development. Climate change is expected to have serious environmental, economic and social impacts on Sri Lanka. Coconut growers' knowledge, perception level and adoption for climate change adaptation measures have influenced productivity of the coconut cultivation. The study investigated the coconut growers' knowledge gap, knowledge and perception levels regarding impacts of climate change in Gampaha and Puttalam districts. Further, this study investigated their adoption of different adaptation measures. A stratified random sampling technique was applied for selecting 240 respondents from two different districts. Structured questionnaire and interview schedule were used to elicit information from the respondents and data was analyzed with both descriptive and inferential statistics. Adoption rate of the climate change adaptation measures is significantly influenced by coconut growers' knowledge and perception level at varying degrees. The study revealed that most of the growers in two study areas have better knowledge $(>70 \%)$ and perceptions $(>60 \%)$ regarding the gradual changes in the climate and its impact on their coconut cultivation. However, their adaptation behavior is fairly poor $(<50 \%)$ in both districts. Hence government policies should more focused on to coconut growers to have access to affordable credit to increase their ability and flexibility to change adaptation strategies in response to the changing climatic conditions. Increasing growers' access to agricultural extension services and access to information on weather forecasting are very important. In addition, government should improve and promote off-farm income-earning opportunities during dry seasons.

Contribution/Originality: This study is one of the very few studies which use novel index-based approach to investigate coconut growers' knowledge, perception and adoption on impacts of climate change in Gampaha and Puttalam districts.

\section{INTRODUCTION}

Agriculture is the main supportive source for the majority of the rural livelihoods in Sri Lanka. While climate change is a global phenomenon, it is expected to have serious environmental, economic and social impacts to Sri Lanka and its impact on agriculture sector is very high. Agriculture and food security are of serious concerns under 
impact of climate variability pressures. Rahman and Begum [1] and Chen, et al. [2] stated that an increase in intensity and frequency of extreme weather events and climate variability have raised broad concerns over global climatic changes since they affected human livelihood activities and strategies. And also, Sharma, et al. [3] stated that rainfall and temperature are the major hydrology climatic variables often used for characterization of climate change and variability. Furthermore, FAO [4] and World Bank [5] collaboratively emphasized that rainfall variability and other climatic risks account for a significant share of agricultural production decline in developing countries. In Sri Lanka, agriculture sector contributes about $7.0 \%$ of national GDP [6].

Coconut (Cocos nucifera L.) is one of the most important plantation crop in Sri Lanka. It spreads over 400,000 ha of land area in all administrative districts of Sri Lanka except those at the elevations beyond $750 \mathrm{~m}$ amsl $[7,8]$. The annual nut production was 3086 million in 2019 [9]. Coconut industry generates employment for nearly 500,000 people and contributing to nearly $0.6 \%$ of gross domestic production and $3.9 \%$ of foreign exchange earnings [6]. It is cultivated in all three agro-climatic zones of Sri Lanka as 30\% in the wet zone, $50 \%$ in the intermediate zone and $20 \%$ in the dry zone. Being a rain-fed crop, rainfall and temperature are the important climatic factors influencing coconut yield $[10,11]$. Coconut performs well under a mean annual temperature between $27^{\circ} \mathrm{C}-29^{\circ} \mathrm{C}$ and mean annual rainfall of 1250-2500 mm/year [12]. The main coconut growing area consists of three administrative districts within the "Coconut Triangle”: Kurunegala, Puttalam and Gampaha.

Since growers are the managers and ultimate users of a country's agro-biodiversity and resources, growers' involvement in assessing climate change and its impacts is vital. It is important to understand coconut growers' knowledge and perceptions regarding climate change, as growers must first perceive and have knowledge of the causes for the changes in climate and their impact on coconut in order to effectively adapt and have the motivation to do so. Coconut growers' perception of the impacts of climate change, is a prerequisite for the practice of adaptation measures.

Adaptation is important to address the adverse impacts of climate risks. Food security can be increased with adaptation [13-16]. Adaptation refers to adjustments in human-environmental systems in response to observed or expected changes in climatic stimuli $[17,18]$. Adaptation to climate change requires the farmers' first notice of the change in climate, and then identification of useful adaptations and implementation of them [19]. This study investigates the differences in coconut growers' knowledge level, perception level and ability to implement adaptation measures in Gampaha and Puttalam districts. Hence it is expected that their knowledge index, perception index and adoption index will vary based on the personal view and the social impact of the surrounding environment.

\section{METHODOLOGY}

\subsection{Study Area}

The study was conducted in Gampaha and Puttalam districts, which were considered as two major areas belongs to coconut triangle. When considering the Gampaha district, it lies approximately between longitude $80^{\circ} \mathrm{O}^{\prime}$ $51.7176^{\prime \prime} \mathrm{E}$ and latitude $7^{\circ} 5^{\prime} 14.3160^{\prime \prime} \mathrm{N}$. This region made up of 13 Divisional Secretarial divisions (Figure 1) and 26 Agrarian Service divisions. It was in Western province and composed of two main Agro Ecological Zones as Low country Wet Zone (WL) and Low country Intermediate Zone (IL). The mean annual rain fall was $2580 \mathrm{~mm}$, which varies from $2300 \mathrm{~mm}$ to $2800 \mathrm{~mm}$ and the mean annual temperature was $28^{\circ} \mathrm{C}$, which varies from $26^{\circ} \mathrm{C}$ to $30^{\circ} \mathrm{C}$. Whereas, Puttalam district which lies approximately between longitude $79^{\circ} 49^{\prime} 41.88^{\prime \prime} \mathrm{E}$ and latitude $8^{\circ} \mathrm{O} 2^{\prime}$ 10.32" N is made up of 16 Divisional Secretarial divisions (Figure 2) and 18 Agrarian Service divisions. It was in North Western province and composed of two main Agro Ecological Zones as Low country Intermediate (IL1, IL3) and Low country Dry (DL1, DL3). The mean annual rain fall was $1300 \mathrm{~mm}$, which varies from $1200 \mathrm{~mm}$ to 1600 $\mathrm{mm}$ and the mean annual temperature was $30.5^{\circ} \mathrm{C}$, which varies from $29^{\circ} \mathrm{C}$ to $32^{\circ} \mathrm{C}$. Relative to Gampaha district, temperature is generally high and annual rainfall is very low in this region. 


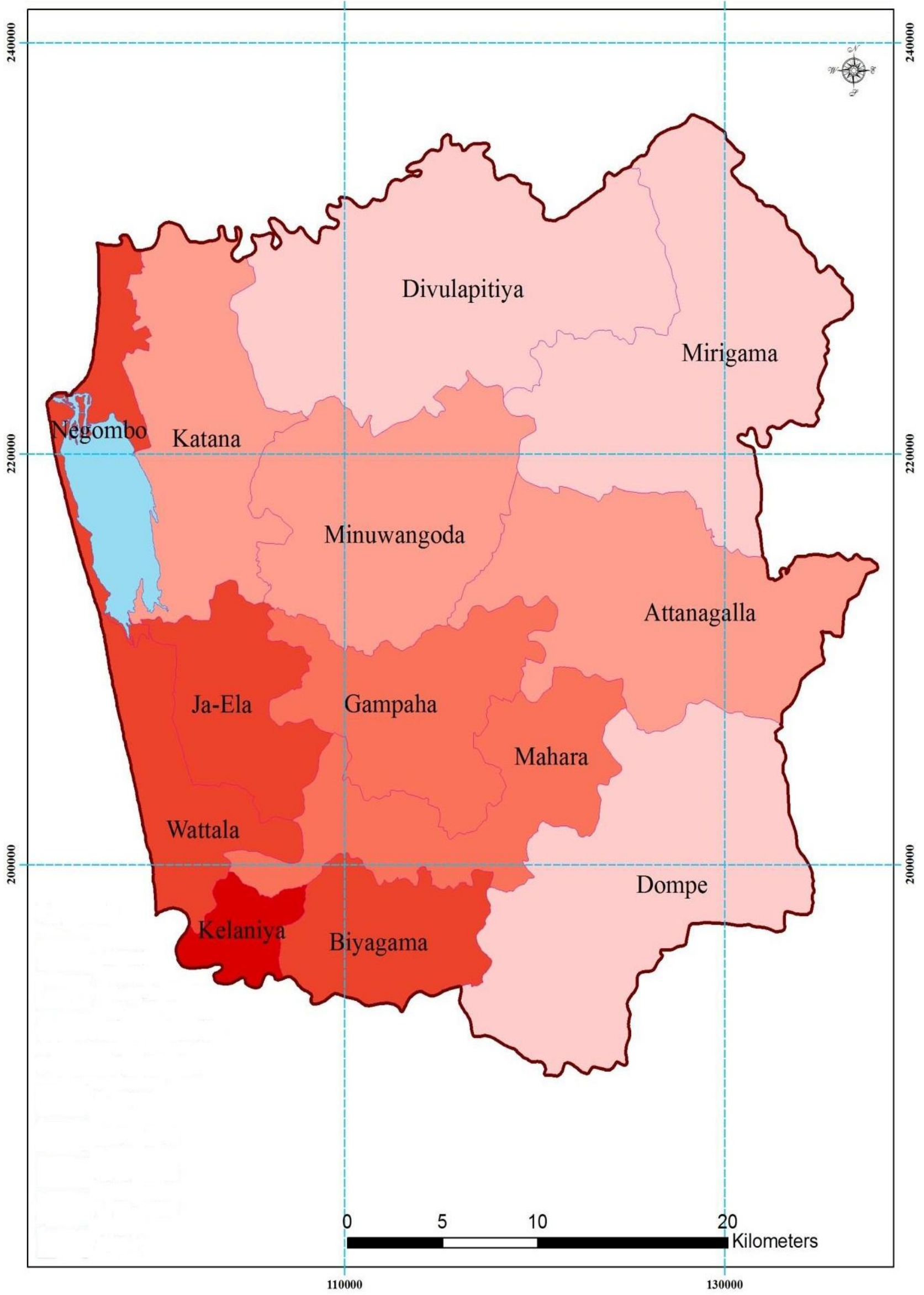

Figure-1. Map of Gampaha District indicating Divisional Secretarial Divisions. 


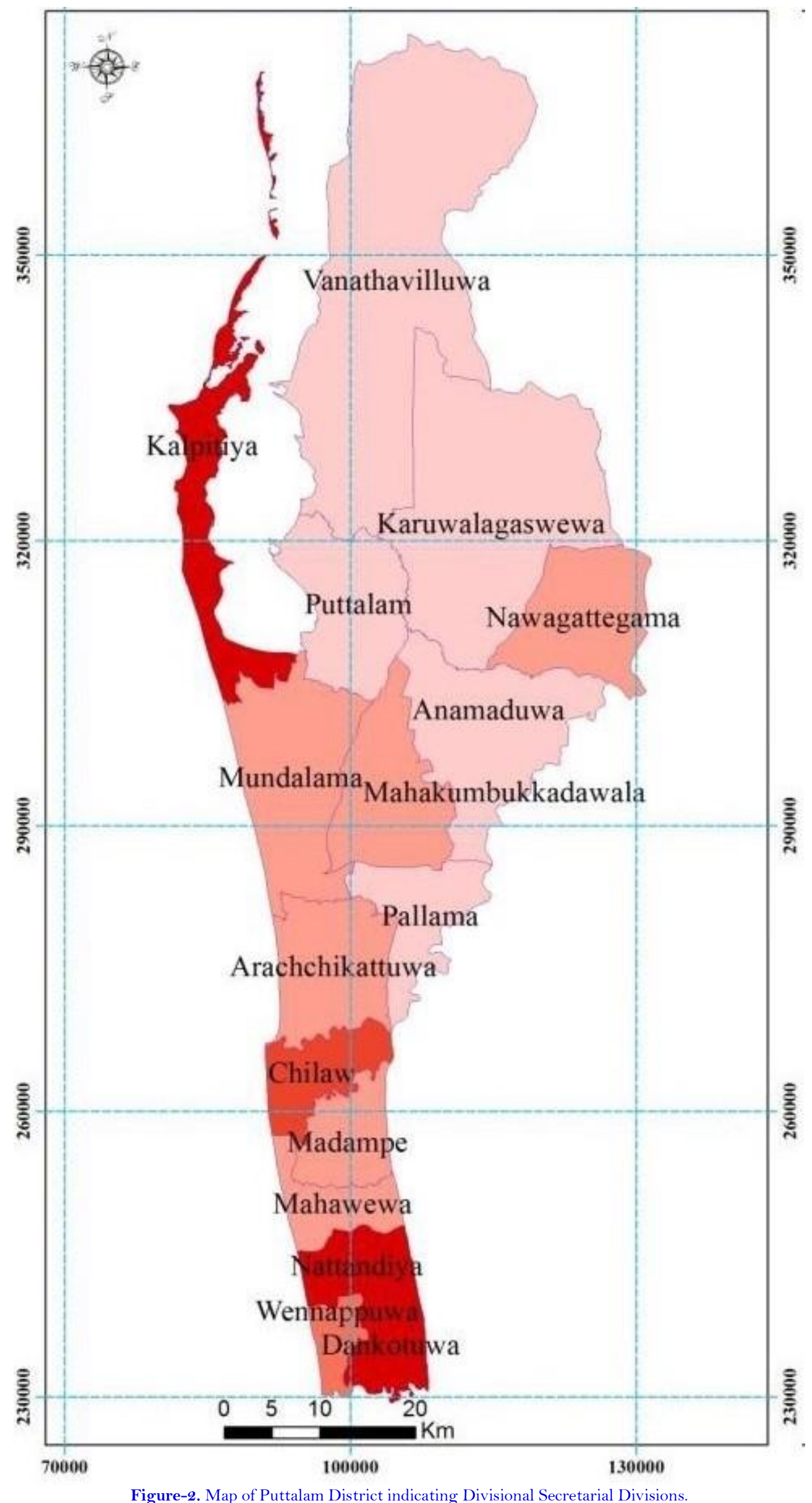

Figure-2. Map of Puttalam District indicating Divisional Secretarial Divisions. 


\subsection{Sampling Procedure and Sample}

As this study was conducted in Gampaha and Puttalam districts, the study sample comprised of 100 coconut growers from Gampaha and 140 coconut growers from Puttalam, which were selected according to stratified random sampling method throughout the respective districts. The heads of the selected households or their spouses were interviewed using both 10-point Likert scale type and semi-structured questionnaire and group discussions were done with randomly selected group of coconut growers in selected districts. In this study, selected psychological object was "impacts of climate change on coconut". Therefore, coconut growers were interviewed with using 10-point Likert scale questionnaire and the scale was designed to administer coconut growers' knowledge, perception and adoption on impacts of climate change in Gampaha and Puttalam districts. In addition, semi structured questions were used to elicit information on coconut growers' socio demographic profile.

Likert scale is widely used in behavioral researches. It will help researchers to develop correct scales to measure knowledge, perception and adoption. A Likert item is simply a statement where respondents evaluate a quantitative value on any kind of subjective or objective agreement/disagreement. Well-designed Likert items exhibit "symmetry" in that they contain equal numbers of positive and negative positions whose respective distances apart are bilaterally symmetric about the "neutral"/zero value [20].

Data collected were subjected to both descriptive and inferential statistics such as percentages, mean, standard deviation and knowledge, perception and adoption indexes and analyzed using SPSS (version 23).

\subsection{Knowledge Gap and overall Knowledge Index (KI)}

Knowledge gap states the difference between the climate change dimensions and the knowledge on the same possessed by coconut growers. To calculate the knowledge gap of coconut growers, a list of climate change dimensions were compiled during survey conducted in each research areas in Gampaha and Puttalam districts. In determining knowledge gap, climate change dimension wise score was assigned 0 to 10 in the knowledge test. Overall score of 16 questions was 160 and each question carried 10 scores. The difference between obtainable score and obtained score indicated the knowledge gap of the coconut growers. This deviation was then expressed in percentage as the proportion to the grower's maximum possible score [21, 22].

The Knowledge Gap Index was computed as;

$$
K G I=\frac{K p-K o}{K p} X 100
$$

Where,

KGI = Knowledge Gap Index.

$\mathrm{Kp}=$ Maximum possible score of a coconut grower .

Ko $=$ Obtained knowledge score by a coconut grower .

The value of knowledge gap index was lied between $\mathrm{O}$ and 100. The value of index closer to zero indicated the lower knowledge gap, while that closer to 100 indicated the larger knowledge gap.

Coconut growers' knowledge level was measured by using 16 statements. Each climate change dimension was measured independently, and an overall knowledge was calculated through the knowledge index [23].

$$
\text { Knowledge Index }=\frac{\text { Score obtained by respondents }}{\text { Maximum possible score }} X 100
$$

The value of knowledge index was lied between $\mathrm{o}$ and 100. The value of index closer to zero indicated the lower level of knowledge about impacts of climate change, while that closer to 100 indicated the larger level of knowledge. 


\subsection{Perception Index (PI)}

Coconut growers' perception level was measured by using 31 statements.

$$
\text { Perception Index }=\frac{\text { Score obtained by respondents }}{\text { Maximum possible score }} \times 100
$$

The value of perception index was lied between 0 and 100. The value of index closer to zero indicated the lower level of perception about impacts of climate change, while that closer to 100 indicated the larger level of perception.

\subsection{Adoption Index (AI)}

Adoption is an aggregation of adoption of different dimensions of adaptation strategies to overcome the impacts of climate change in coconut cultivation. For this study, an index was constructed for each district based on available data from coconut growers. This district-wise adoption index would be used in the identification of the districts that require intervention to change the pattern of adoption. Coconut growers' adoption level was measured by using 14 statements.

\section{Adoption Index $=\frac{\text { Score obtained by respondents }}{\text { Maximum possible score }} \times 100$}

Finally, it will be represented as percentage. The value of status index was non-negative and lied between 0 and 100. The value of index closer to zero indicated the lower level of adoption, while that closer to 100 indicated the higher level of adoption.

\section{RESULTS AND DISCUSSION}

\subsection{Socioeconomic Characteristics of Respondents in Gampaha and Puttalam Districts}

Results in Table 1 shows some socioeconomic characteristics of coconut growers measured in the two study areas of Gampaha and Puttalam districts. The results reveal that the majority of coconut growers in both districts were in "> 50" year age category. It was $65 \%$ in Gampaha district followed by $57.86 \%$ in Puttalam district. Most of them (80\% in Gampaha and $85.71 \%$ in Puttalam) were male more than female, which may be due to the sociocultural structure of the country and majority (92\% in Gampaha and 99.28\% in Puttalam) of them are married in both districts. It is evident that majority (55\%) of the growers' in Gampaha district having 4-5 family members in their families followed by $62.86 \%$ in Puttalam district having 2-3 family members in their families. The distribution of growers' education level shows that majority of the growers in both districts $43 \%$ in Gampaha and $55 \%$ in Puttalam) had education up to G.C.E. (A/L). As regards land holding, 72\% of the growers in Gampaha and $80.71 \%$ in Puttalam were having "2-25Ac" land category and in terms of farming experience, about $43 \%$ of growers in Gampaha had more than 30 years of farming experience followed by 59.28\% in Puttalam had about 5-10 years farming experience. Further, majority of the growers in both districts (92\% in Gampaha and 97.86\% in Puttalam) reported that land ownership as their own.

\subsection{Coconut Growers' Knowledge Level on Impacts of Climate Change}

Results in Table 2 shows that the coconut growers' level of knowledge and gap on impacts of climate change on coconut cultivation in two different districts. Sixteen climate change dimensions were identified and believed to be understand by coconut growers as they are the most influential factors for cause climate change. Findings shows that, majority of the coconut growers in both districts had lower knowledge gap index (KGI) under climate change dimensions as "Human activities are the leading form for climate change" (8\% for Gampaha and $11.36 \%$ for Puttalam) and "Deforestation has a big impact on increase in temperature" (8\% for Gampaha and $9.93 \%$ for Puttalam). 
Table-1. Distribution of respondents by socioeconomic characteristics $(n=240)$.

\begin{tabular}{|c|c|c|c|c|c|c|}
\hline \multirow[t]{2}{*}{ No } & \multirow[t]{2}{*}{ Variables } & \multirow[t]{2}{*}{ Group } & \multicolumn{2}{|c|}{ Gampaha District $(n=100)$} & \multicolumn{2}{|c|}{ Puttalam District $(n=140)$} \\
\hline & & & Frequency & Percentage (\%) & Frequency & Percentage (\%) \\
\hline \multirow[t]{4}{*}{1} & Age (Years) & $<30$ & $\mathrm{O} 2$ & $\mathrm{O} 2$ & $\mathrm{O}$ & 0 \\
\hline & & $30-40$ & 12 & 12 & O4 & 2.86 \\
\hline & & $40-50$ & 21 & 21 & 55 & 39.28 \\
\hline & & $>50$ & 65 & 65 & 81 & 57.86 \\
\hline \multirow[t]{2}{*}{2} & Gender & Male & 80 & 80 & 120 & 85.71 \\
\hline & & Female & 20 & 20 & 20 & 14.29 \\
\hline \multirow[t]{2}{*}{3} & Marital Status & Single & 08 & 08 & 01 & 0.71 \\
\hline & & Married & 92 & 92 & 139 & 99.28 \\
\hline \multirow[t]{5}{*}{3} & $\begin{array}{l}\text { Landholding } \\
\text { (Acres) }\end{array}$ & $<2 \mathrm{Ac}$ & 20 & 20 & $\mathrm{O}$ & $\mathrm{O}$ \\
\hline & & $2-25 \mathrm{Ac}$ & 72 & 72 & 113 & 80.71 \\
\hline & & $25-50 \mathrm{Ac}$ & 7 & 7 & 25 & 17.86 \\
\hline & & $50-100 A c$ & 1 & 1 & 2 & 1.43 \\
\hline & & $>100 A c$ & $\mathrm{O}$ & $\mathrm{O}$ & $\mathrm{O}$ & $\mathrm{O}$ \\
\hline \multirow[t]{4}{*}{4} & Family Size & $2-3$ & 37 & 37 & 88 & 62.86 \\
\hline & & $4-5$ & 55 & 55 & 46 & 32.86 \\
\hline & & $6-7$ & 6 & 6 & 6 & 4.28 \\
\hline & & $>7$ & 2 & 2 & $\mathrm{O}$ & \\
\hline \multirow[t]{5}{*}{5} & Education & Up to Grade 5 & 1 & 1 & $\mathrm{O}$ & $\mathrm{O}$ \\
\hline & & Up to Grade 8 & 3 & 3 & 7 & 5 \\
\hline & & Up to $\mathrm{O} / \mathrm{L}$ & 24 & 24 & 32 & 22.86 \\
\hline & & $\mathrm{Up}$ to $\mathrm{A} / \mathrm{L}$ & 43 & 43 & 77 & 55 \\
\hline & & $\begin{array}{c}\text { Diploma/Gra } \\
\text { duate }\end{array}$ & 29 & 29 & 24 & 17.14 \\
\hline \multirow[t]{5}{*}{6} & $\begin{array}{c}\text { Farming } \\
\text { Experience } \\
\text { (Years) }\end{array}$ & $<5$ & 3 & 3 & 1 & 0.71 \\
\hline & & $5-10$ & 21 & 21 & 83 & 59.28 \\
\hline & & $11-20$ & 16 & 16 & 45 & 32.14 \\
\hline & & $21-30$ & 17 & 17 & 5 & 3.57 \\
\hline & & $>30$ & 43 & 43 & 6 & 4.28 \\
\hline \multirow[t]{3}{*}{7} & $\begin{array}{c}\text { Land } \\
\text { Ownership }\end{array}$ & Own & 92 & 92 & 137 & 97.86 \\
\hline & & Common & 7 & 7 & 2 & 1.43 \\
\hline & & Rent/Tenant & 1 & 1 & 1 & 0.71 \\
\hline
\end{tabular}

Further, results revealed that, most of the coconut growers in two districts believe that they are currently experiencing the impacts of climate change, which was proved by having $8.9 \%$ of KGI from Gampaha and 13.57\% of KGI from Puttalam. The study revealed that coconut growers in Gampaha district had 82.74\% of knowledge index (KI) while $73.37 \%$ KI in Puttalam. Results show that respondents in Gampaha district had 11.6\% KGI for climate change dimension of "There is a change in regular temperature variation pattern throughout the year than early years" while it was $18.5 \%$ in Puttalam district. In addition, findings showed that respondents in Gampaha district had lower KGI for all climate change dimensions with compared to KG indices in Puttalam district.

\subsection{Coconut Growers' Perceptions of Climate Change and Variability}

The findings from the coconut growers' perceptions regarding changes and impacts of climate change are presented in Table 3. The results revealed that majority of the growers in these two districts are experiencing aberrations in the climate as they have been farming within the region for many years. Most of the growers (nearly $80 \%$ and above) in two districts perceived increase in atmospheric temperature and fluctuations in rainfall during the past ten years. 
Table-2. Distribution of coconut growers by Knowledge Gap in Gampaha and Puttalam.

\begin{tabular}{|c|c|c|c|}
\hline No. & Climate change dimensions & $\begin{array}{c}\text { KG Index (\%) } \\
\text { [Gampaha } \\
\text { District }] \\
(\mathrm{N}=100)\end{array}$ & $\begin{array}{c}\text { KG Index (\%) } \\
\text { [Puttalam } \\
\text { District] } \\
(\mathrm{N}=140)\end{array}$ \\
\hline 1 & $\begin{array}{l}\text { Change in regular temperature variation pattern throughout the } \\
\text { year than early years }\end{array}$ & 11.6 & 18.5 \\
\hline 2 & Change in regular rainfall pattern than early years & 13.3 & 18.71 \\
\hline 3 & Climate change causes rise in sea levels & 25.1 & 37.5 \\
\hline 4 & $\begin{array}{l}\text { Climate change causes changes in wind velocity and wind } \\
\text { directions }\end{array}$ & 25.4 & 41.3 \\
\hline 5 & Climate change leads to coastal erosion & 22.3 & 33.43 \\
\hline 6 & $\begin{array}{l}\text { Climate change causes increase in intensity of extreme weather } \\
\text { events (ex: heat waves, tornadoes, cyclones, heavy rainfalls) }\end{array}$ & 20.5 & 34.43 \\
\hline 7 & Human activities are the leading form for climate change & 8 & 11.36 \\
\hline 8 & $\begin{array}{l}\text { Burning vehicle fuels, oil and gases cause for air pollution and } \\
\text { increase in atmospheric temperature }\end{array}$ & 8.7 & 18.21 \\
\hline 9 & $\begin{array}{l}\text { Green-house gas emissions have a greater impact on climate } \\
\text { change }\end{array}$ & 27 & 37.5 \\
\hline 10 & Green-house gas emission causes boost in temperature & 26.2 & 36.71 \\
\hline 11 & Deforestation has a big impact on increase in temperature & 8 & 9.93 \\
\hline 12 & $\begin{array}{l}\text { Heavy use of fertilizers (specially } \mathrm{N} \text { containing fertilizers) causes } \\
\text { for climate change }\end{array}$ & 27.6 & 44.71 \\
\hline 13 & Increased population growth has an effect on climate change & 17.9 & 25.36 \\
\hline 14 & $\begin{array}{l}\text { Rapid urbanization and changes in life style have an effect on } \\
\text { climate change }\end{array}$ & 15 & 24 \\
\hline 15 & Currently experiencing the impacts of climate change & 8.9 & 13.57 \\
\hline 16 & Climate change is a threat to sustainable development? & 10.7 & 20.86 \\
\hline
\end{tabular}

Out of the total respondents, $86.1 \%$ and $73 \%$ perceived north-east (NEM) and south-west monsoon (SWM) seasons were not starting at correct time over the last 5 years in Gampaha and Puttalam districts respectively. Differences in perception index indicates that growers who are in Gampaha district more likely to perceive a fluctuation (increase/ decrease) in amount of rainfall over the last 5 years (89.2\%) compared to those in Puttalam $(76.6 \%)$ and longer dry periods and short rainy periods over the last 5 years $(89 \%)$ compared to those in Puttalam $(75.3 \%)$. Besides to perceiving the fluctuations and length of rainfall in the studied area, almost $85 \%$ in Gampaha and $70.3 \%$ in Puttalam, growers believed that inter monsoonal rains were not starting at correct time over the last 5 years, respectively. In addition, growers in Gampaha district had higher perception index (80.4\%) for increase in run off over the last 5 years than growers in Puttalam district (64.2\%). This fluctuation in amount of rainfall, and unreliability of raining time impede the agricultural planning that attracts appropriate adaptation strategies.

Furthermore, growers in Gampaha district had perceived that there is no any harmful effects to coconut cultivation over the past 10 years due to droughts conditions (28.8\%), there is no any impact of droughts on livelihood and household over the past 10 years $(24.3 \%)$, there is no any impact of floods on coconut cultivation over the past 10 years (44.5\%) and there is no any impact of floods on livelihood and household over the past 10 years $(32.9 \%)$ with compared to growers in Puttalam district as $6.1 \%, 5.7 \%, 59.4 \%$ and $53.8 \%$ respectively. According to the results in Table 3, respondents in Gampaha had 81 percent perception index for "increase in drought conditions in different agro-ecological regions over the last 10 years" and 63 percent in Puttalam; as well as 84.6 percent perception index was obtained by respondents in Gampaha for "climate change influences agricultural yields negatively" while it was 77.3 percent in Puttalam. However, very low level of perception index was obtained by Gampaha (20.5\%) and Puttalam (6.1\%) districts respondents for "believe of climate change has no any serious cause for economic depression to our country". Moreover, coconut growers in both districts had more than $75 \%$ perception index for "believe of climate change poses threats to food security" and almost $85 \%$ perception index for "agreeing and feeling that climate change is really happening". 
Table-3. Coconut growers' level of perception on the impacts of climate change and its variability.

\begin{tabular}{|c|c|c|c|}
\hline No. & $\begin{array}{l}\text { Climate Change Dimensions } \\
\text { (General) }\end{array}$ & $\begin{array}{c}\text { Perception } \\
\text { Index (\%) } \\
\text { [Gampaha } \\
\text { District] } \\
(\mathrm{N}=100)\end{array}$ & $\begin{array}{c}\text { Perception Index } \\
(\%) \\
{[\text { Puttalam }} \\
\text { District }] \\
(\mathrm{N}=140)\end{array}$ \\
\hline 1 & I think that climate change is more harmful than beneficial, in general & 86.5 & 76.3 \\
\hline 2 & $\begin{array}{l}\text { I feel that the atmospheric temperature has been increasing over the past } \\
10 \text { years }\end{array}$ & 90.2 & 80.6 \\
\hline 3 & I have noticed that change in rainfall over the past 10 years & 98.1 & 79.8 \\
\hline 4 & I have noticed that increase in heavy rains over the last 5 years & 82 & 71.5 \\
\hline 5 & I have noticed that change in rainfall seasonality over the last 5 years & 90.1 & 77.4 \\
\hline 6 & $\begin{array}{l}\text { I have noticed that fluctuation (increase/ decrease) in amount of rainfall } \\
\text { over the last } 5 \text { years }\end{array}$ & 89.2 & 76.6 \\
\hline 7 & $\begin{array}{l}\text { I have noticed that longer dry periods and short rainy periods over the last } \\
5 \text { years }\end{array}$ & 89 & 75.3 \\
\hline 8 & $\begin{array}{l}\text { I have noticed that NEM and SWM monsoon seasons were not starting } \\
\text { at correct time over the last } 5 \text { years }\end{array}$ & 86.1 & 73.0 \\
\hline 9 & $\begin{array}{l}\text { I have noticed that the inter monsoonal rains were not starting at correct } \\
\text { time over the last } 5 \text { years }\end{array}$ & 85 & 70.3 \\
\hline 10 & I have noticed that the increase in run off over the last 5 years & 80.4 & 64.2 \\
\hline 11 & $\begin{array}{l}\text { I feel that there is no any harmful effects to coconut cultivation over the } \\
\text { past } 10 \text { years due to droughts conditions }\end{array}$ & 28.8 & 6.1 \\
\hline 12 & $\begin{array}{l}\text { I feel that there is no any impact of droughts on livelihood and household } \\
\text { over the past } 10 \text { years }\end{array}$ & 24.3 & 5.7 \\
\hline 13 & $\begin{array}{l}\text { I feel that there is no any impact of floods on coconut cultivation over the } \\
\text { past } 10 \text { years }\end{array}$ & 44.5 & 59.4 \\
\hline 14 & $\begin{array}{l}\text { I feel that there is no any impact of floods on livelihood and household } \\
\text { over the past } 10 \text { years }\end{array}$ & 32.9 & 53.8 \\
\hline 15 & $\begin{array}{l}\text { I have noticed that increase in drought conditions in different agro- } \\
\text { ecological regions over the last } 10 \text { years }\end{array}$ & 81 & 63.0 \\
\hline 16 & $\begin{array}{l}\text { I have noticed that climate change influences agricultural yields } \\
\text { negatively }\end{array}$ & 84.6 & 77.3 \\
\hline 17 & $\begin{array}{l}\text { However I believe that climate change has no any serious cause for } \\
\text { economic depression to our country }\end{array}$ & 20.5 & 6.1 \\
\hline 18 & I believe that climate change poses threats to food security & 81.1 & 76.1 \\
\hline \multirow[t]{2}{*}{19} & I feel that climate change is really happening & 86.1 & 84.8 \\
\hline & \multicolumn{3}{|l|}{ Climate Change Dimensions (On coconut) } \\
\hline 20 & $\begin{array}{l}\text { I have noticed that decline in coconut yield during last 5-10 years in my } \\
\text { estate }\end{array}$ & 81.4 & 73.8 \\
\hline 21 & $\begin{array}{l}\text { I have noticed that yellowing and drooping of more number of coconut } \\
\text { fronds during dry periods }\end{array}$ & 83.9 & 73.8 \\
\hline 22 & $\begin{array}{l}\text { I have noticed that wilting and drying of more number of coconut fronds } \\
\text { during dry periods }\end{array}$ & 83.3 & 70.8 \\
\hline 23 & $\begin{array}{l}\text { I have noticed that inflorescence abortion during dry periods over the last } \\
5 \text { years }\end{array}$ & 73.5 & 37.8 \\
\hline 24 & $\begin{array}{l}\text { I have noticed that falling of more number of button nuts during dry } \\
\text { periods over the last } 5 \text { years }\end{array}$ & 83.7 & 72.8 \\
\hline 25 & $\begin{array}{l}\text { I have noticed that lowering of the ground water level in my estate over } \\
\text { the last } 5-10 \text { years }\end{array}$ & 80.6 & 72.0 \\
\hline 26 & $\begin{array}{l}\text { I have noticed that changing fertilizer type into organic may help to } \\
\text { reduce effects of climate change }\end{array}$ & 72.4 & 62.7 \\
\hline 27 & $\begin{array}{l}\text { I have noticed that there is no any effect to intercropping under coconut } \\
\text { due to climate change over the last } 5-10 \text { years }\end{array}$ & 80 & 60.8 \\
\hline 28 & $\begin{array}{l}\text { I have noticed any increase of pest and disease infestations on coconut } \\
\text { during last } 5 \text { years due to climate change }\end{array}$ & 82.3 & 69.3 \\
\hline 29 & $\begin{array}{l}\text { I have noticed that any increase of pest and disease infestations on other } \\
\text { agricultural crops during last } 5 \text { years due to climate change }\end{array}$ & 79.1 & 56.7 \\
\hline 30 & I have exposed to mass media about climate change & 78.1 & 62.8 \\
\hline 31 & $\begin{array}{l}\text { I have access to social capital (farm-to-farm extension and the no. of } \\
\text { relatives in the village) }\end{array}$ & 78.2 & 69.1 \\
\hline
\end{tabular}

\subsection{Coconut Growers' Perceptions of Climate Change Dimensions on Coconut}

Generally, the majority of coconut growers are aware about the presence of climate change and variability. They revealed that their local experience of climate change and variations, using variability in onset and cessation 
time of the rainy season, fluctuation (increase/ decrease) in amount of rainfall over the last 5 years, longer dry periods and short rainy periods over the last 5 years, increase of atmospheric temperature and etc. Moreover, $81.4 \%$ of perception index had obtained by coconut growers in Gampaha for "decline in coconut yield during last 5-10 years in their estates" while it was $73.8 \%$ in Puttalam. In addition, higher perception indices were noticed from growers in Gampaha for yellowing and drooping of more number of coconut fronds during dry periods (83.9\%), wilting and drying of more number of coconut fronds during dry periods (83.3\%), inflorescence abortion during dry periods over the last 5 years $(73.5 \%)$, falling of more number of button nuts during dry periods over the last 5 years $(83.7 \%)$, death of more number of palms during dry periods over the last 5 years $(65.8 \%)$ with compared to growers in Puttalam as $73.8 \%, 70.8 \%, 37.8 \%, 72.8 \%$ and $25.7 \%$ respectively. And also results in Table 3 indicated that Gampaha district had shown high perception indices for lowering of the ground water level in their estates over the last 5 - 10 years $(80.6 \%)$, changing fertilizer type into organic may help to reduce effects of climate change $(72.4 \%)$, there is no any effect to intercropping under coconut due to climate change over the last 5-10 years (80\%), any increase of pest and disease infestations on coconut during last 5 years due to climate change (82.3\%), any increase of pest and disease infestations on other agricultural crops during last 5 years due to climate change (79.1\%) with compared to Puttalam district such as $72 \%, 62.7 \%$, 60.8\%, 69.3\% and 56.7\% respectively. At last, growers in Gampaha had $78.1 \%$ perception index for exposure to mass media about climate change while Puttalam had $62.8 \%$ and $78.2 \%$ and $69.1 \%$ perception index for access of social capital (farm-to-farm extension and the no. of relatives in the village) for growers in Gampaha and Puttalam districts respectively.

Table-4. Coconut growers' level of adoption on the impacts of climate change.

\begin{tabular}{|c|c|c|c|}
\hline No. & Adaptation Measure & $\begin{array}{c}\text { Adoption Index } \\
\text { (\%) [Gampaha } \\
\text { District] } \\
(\mathrm{N}=100)\end{array}$ & $\begin{array}{c}\text { Adoption Index } \\
\text { (\%) [Puttalam } \\
\text { District }] \\
(\mathrm{N}=140)\end{array}$ \\
\hline 1 & Practice rain water harvesting methods in the estate & 47.8 & 37.64 \\
\hline 2 & Construct an irrigation well in the estate & 30 & 15.79 \\
\hline 3 & Apply moisture conservation methods in the estate & 74.2 & 74.93 \\
\hline 4 & Practice soil conservation methods in the estate & 72.1 & 29.07 \\
\hline 5 & $\begin{array}{l}\text { Use of horse/sprinkler/drip irrigation system during dry } \\
\text { periods }\end{array}$ & 18.2 & 62.57 \\
\hline 6 & Use of tube wells & 9 & 54.07 \\
\hline 7 & Practice manual watering during dry periods & 37.6 & 18.64 \\
\hline 8 & $\begin{array}{l}\text { Practice making agro forestry system to reduce temperature } \\
\text { in the estate }\end{array}$ & 42.1 & 49.0 \\
\hline 9 & Plant drought tolerant varieties & 45.1 & 55.21 \\
\hline 10 & $\begin{array}{l}\text { Access to agricultural extension services provided for } \\
\text { coconut, intercropping and livestock production }\end{array}$ & 76.3 & 59.14 \\
\hline 11 & Access of information on weather forecasting & 64.2 & 35.5 \\
\hline 12 & Go for off-farm occupation during dry seasons & 7.7 & 2.71 \\
\hline 13 & Practice planting at the onset of rainy seasons & 90.6 & 97.07 \\
\hline 14 & Apply organic manure to improve the soil conditions & 78.7 & 63.71 \\
\hline
\end{tabular}

\subsection{Coconut Growers' Adoption Level on Impact of Climate Change}

The results in Table 4 indicated that coconut growers in Puttalam district had 97.07\% adoption index for 'Practice planting at the onset of rainy seasons" while growers in Gampaha district had 90.6\%. As evident from the results, majority of the growers in Puttalam district had slightly higher adoption index (74.93\%) for apply moisture conservation methods in their estates than Gampaha district (74.2\%). Further, respondents in Gampaha district had $78.7 \%$ adoption index for apply organic manure to improve the soil conditions whereas it was $63.71 \%$ in Puttalam district. In addition, respondents in Gampaha district had high adoption indices for access to agricultural extension services provided for coconut, intercropping and livestock production (76.3\%), access of information on weather forecasting (64.2\%), currently practicing soil conservation methods (72.1\%),currently practicing rain water 
harvesting methods (47.8\%), practice manual watering during dry periods (37.6\%), construct irrigation wells in their estates (30\%) while respondents in Puttalam district had 59.14\%, 35.5\%, 29.07\%, 37.64\%, 18.64\% and 15.79\% adoption indices respectively. However, growers in Puttalam had high adoption indices for use of horse/sprinkler/drip irrigation system during dry periods (62.57\%), use of tube wells (54.07\%), plant drought tolerant varieties $(55.21 \%)$ and practice making agro-forestry system to reduce temperature in the estate (49.0\%) than growers in Gampaha district.

\section{CONCLUSION}

Changing climate and its impacts remain a major problem in the field of agriculture. Hence the same obstacle is arising for the coconut cultivation in Sri Lanka. Therefore, this study focused to investigate the indices on knowledge, perception and adoption on impacts of climate change among coconut growers' for Gampaha and Puttalam districts. The findings showed that the overall indices for knowledge were $82.74 \%$ for Gampaha and $73.37 \%$ for Puttalam. The overall perception indices were $74.46 \%$ and $62.06 \%$ for both districts respectively. Finally, overall adoption indices of both Gampaha and Puttalam districts were $49.54 \%$ and $46.79 \%$ respectively.

Further, coconut growers' knowledge, perceptions and adoption measures on impacts of climate change in two study areas, show that most of the growers have better knowledge $(>70 \%)$ and perceptions $(>60 \%)$ regarding the gradual changes in the climate and its impact on their coconut cultivation. However, their adaptation behavior is fairly poor $(<50 \%)$ in both districts. Therefore, this research has brought out the usefulness of both studies on growers' knowledge level and studies on growers' perception level. Combining both data sources together inform debates on the need for more inclusive adaptation and development policies on climate change. A number of coconut growers in the study areas are aware of the increasing temperature trend, the late onset of rains, fluctuation in rainfall pattern / amount and the increasing drought frequency.

This study shows that even though coconut growers' behaviour may be influenced by their values and interests, their awareness of weather and climate may also be considered as a consistent indicator of their perception. For that reason, growers observe the local climatic conditions and respond through decisions on their coconut cultivations and adaptation to climate change according to what they perceive.

The study findings showed that, majority of the coconut growers in both districts had lower knowledge gap index (KGI) under climate change dimensions as "Human activities are the leading form for climate change" ( $8 \%$ for Gampaha and $11.36 \%$ for Puttalam) and "Deforestation has a big impact on increase in temperature?" (8\% for Gampaha and $9.93 \%$ for Puttalam). Further, study revealed that coconut growers in Gampaha district had $82.74 \%$ of knowledge index (KI) while $73.37 \%$ KI in Puttalam. The study results revealed that majority of the growers in these two districts are experiencing aberrations in the climate as they have been farming within the region for many years. Most of the growers (nearly $80 \%$ and above) in two districts perceived increase in atmospheric temperature and fluctuations in rainfall during the past ten years. Finally, the results indicated that coconut growers in Puttalam district had 97.07\% adoption index for 'Practice planting at the onset of rainy seasons" while growers in Gampaha district had $90.6 \%$. Although coconut growers in two districts are well aware of climatic changes and its impacts, only few seems to take steps to adjust their farming activities. Government policies should therefore ensure that coconut growers have access to affordable credit to increase their ability and flexibility to change adaptation strategies in response to the changing climatic conditions. Because access to water for irrigation increases the resilience of impact of climate change and variability, and irrigation investment needs should be reconsidered to allow growers to increase water control to counteract adverse impacts from climate change and variability. More importantly, increasing growers' access to agricultural extension services and access to information on weather forecasting are of great need. Furthermore, government should improve and promote off-farm income-earning opportunities during dry seasons. 
Funding: This study was carried out with the financial support from Department of Plantation Management, Faculty of Agriculture, Wayamba University of Sri Lanka, Makandura.

Competing Interests: The authors declare that they have no competing interests.

Acknowledgement: The authors wish to thank Coconut Research Institute for giving approval to carry out this research program and coconut growers for their collaboration in interview and Regional Managers and Coconut Development Officers attached to major coconut growing regions in Coconut Cultivation Board for providing their fullest cooperation to success this project.

\section{REFERENCES}

[1] A. Rahman and M. Begum, "Application of non-parametric test for trend detection of rainfall in the largest island of Bangladesh," Journal of Earth Sciences, vol. 2, pp. 40-44, 2013.

[2] P.-C. Chen, Y.-H. Wang, G. J.-Y. You, and C.-C. Wei, "Comparison of methods for non-stationary hydrologic frequency analysis: Case study using annual maximum daily precipitation in Taiwan," Journal of Hydrology, vol. 545, pp. 197-211, 2017.Available at: https://doi.org/10.1016/j.jhydrol.2016.12.001.

[3] C. S. Sharma, S. N. Panda, R. P. Pradhan, A. Singh, and A. Kawamura, "Precipitation and temperature changes in eastern India by multiple trend detection methods," Atmospheric Research, vol. 180, pp. 211-225, 2016.Available at: https://doi.org/10.1016/j.atmosres.2016.04.019.

[4] FAO, Climate change adaptation and mitigation in the food and agriculture sector. Rome, Italy: FAO, 2008.

[5] World Bank, Social protection sector strategy: From safety net to springboard. Washington, DC, USA: E World Bank Group, 2002.

[6] Economic and Social Statistics of Sri Lanka, "Department of census and statistics," ed Colombo, Sri Lanka: Central Bank of Sri Lanka, 2020, p. 2.

[7] Central Bank Report of Sri Lanka, "Annual report. Central Bank of Sri Lanka," Colombo, Sri Lanka, Chapter, vol. 6, pp. 39-45, 2016.

[8] L. L. W. Somasiri, N. Nadarajah, L. Amarasinghe, and H. A. J. Gunathilake, Land suitability assessment of coconut growing area in the coconut triangle vol. 3. Lunuwila: Occasional Publication Series, CRI, 1994.

[9] Department of Census and Statistics, Department of census and statistics. Colombo, Sri Lanka, 2020.

[10] T. Peiris, R. Thattil, and R. Mahindapala, "An analysis of the effect of climate and weather on coconut (Cocos nucifera)," Experimental Agriculture, vol. 31, pp. 451-460, 1995.Available at: https://doi.org/10.1017/s0014479700026430.

[11] D. T. Mathes and J. D. J. S. Kularatne, "Uncertainties in rainfall and the impact of the coconut industry in Sri Lanka," presented at the Regional Workshop on Climate Change Vulnerability and Adaptation in Asia and the Pacific, Manila, the Phillipines, 1996.

[12] C. S. Ranasinghe, "Climate change impacts on coconut production and potential adaptation and mitigation measures : A review of current status," in Proceedings of the Workshop on Present Status of Research Cctivities on Climate Change Adaptations (Ed. B. Marambe) 71-82 pp, Council for Agricultural Research Policy. Colombo, 2012.

[13] S. Di Falco, M. Veronesi, and M. Yesuf, "Does adaptation to climate change provide food security? A micro-perspective from Ethiopia . ," American Journal of Agricultural Economics, vol. 93, pp. 829-846, 2011.Available at: https://doi.org/10.1093/ajae/aaroo6.

[14] T. J. Lybbert and D. A. Sumner, "Agricultural technologies for climate change in developing countries: Policy options for innovation and technology diffusion," Food Policy, vol. 37, pp. 114-123, 2012.Available at: https://doi.org/10.1016/j.foodpol.2011.11.001.

[15] S. Di Falco and M. Veronesi, "How can African agriculture adapt to climate change? A counterfactual analysis from Ethiopia," Land Economics, vol. 89, pp. 743-766, 2013.Available at: https://doi.org/10.3368/le.89.4.743.

[16] S. Di Falco, "Adaptation to climate change in Sub-Saharan agriculture: Assessing the evidence and rethinking the drivers," European Review of Agricultural Economics, vol. 41, pp. 405-430, 2014.Available at: https://doi.org/10.1093/erae/jbu014. 
[17] T. B. Below, K. D. Mutabazi, D. Kirschke, C. Franke, S. Sieber, R. Siebert, and K. Tscherning, "Can farmers' adaptation to climate change be explained by socio-economic household-level variables?," Global Environmental Change, vol. 22, pp. 223-235, 2012.

[18] S. Wheeler, A. Zuo, and H. Bjornlund, "Farmers' climate change beliefs and adaptation strategies for a water scarce future in Australia," Global Environmental Change, vol. 23, pp. 537-547, 2013.Available at: https://doi.org/10.1016/j.gloenvcha.2012.11.008.

[19] D. Maddison, "The perception of and adaptation to climate change in Africa," CEEPA Discussion Paper No. 10. Centre for Environmental Economics and Policy in Africa, University of Pretoria, South Africa2006.

[20] A. Leiserowitz, "Climate change risk perception and policy preferences: The role of affect, imagery, and values," Climatic Change, vol. 77, pp. 45-72, 2006.Available at: https://doi.org/10.1007/s 10584-006-9059-9.

[21] S. Kundu, M. Islam, M. Ali, M. Azam, and A. Mozumder, "Correlates of pulses production knowledge gap of the farmers," Journal of Experimental Biology Science, vol. 4, pp. 39-44, 2013.

[22] I. Tomar, S. Garg, R. Yadav, and J. Morya, "Communication gap in chickpea production technology among the chickpea growers," Indian Research Journal of Extension Education, vol. 2, pp. 81-83, 2012.

[23] E. F. Linquist, Educational measurements, Part-II. Washington, USA: American Council of Education, 1951.

Views and opinions expressed in this article are the views and opinions of the author(s), Current Research in Agricultural Sciences shall not be responsible or answerable for any loss, damage or liability etc. caused in relation to/arising out of the use of the content. 